\title{
Military Men and Women Facing Challenges of Adapting to New Military Environment
}

\author{
Jianxin Yang \& Min Yu \\ Military Preventive Medicine Department \\ Fourth Military Medical University, Xi,an 710032, China \\ E-mail: biph_0001@sina.com \\ Fuyong Liu \\ Bethune International Peace Hospital \\ 398 West Zhongshan Road, Shijiazhuang 050082, Hebei, China \\ Tel: 86-311-8799-8900_E-mail: liufy1065@hotmail.com
}

\begin{abstract}
To adapt themselves to the new military environment, the military men and women must recognize the duty of a military person, get accustomed to special way of life in the Army and be on alert for military operations.

The military service is a special career. The role of a military person is decided by his or her duty and obligation to society and restricted by the career and norms of society. Military persons have common personal characters, which are influenced by military operational environment and their life style is characterized by collective or group form, connected by common goals of their operations, and based on special way of living as a group.
\end{abstract}

They must adapt themselves to this form of life and interpersonal environment. Their adaptability to military operations is a comprehensive one, which requires tough physical strength, strong wills, high level of coordination and enhanced personality.

Keywords: Military personnel, Military profession, Military environment, Adaptation

The Army is the cradle of young officers, who grow tougher and stronger in military operations. Those, who have served in the Army, have long-cherished memories and take great pride in themselves and enjoy great spiritual wealth for life.

The dual aspects of adaptability to military environment include self-adaptability to the new changes of environment and change of social and natural environment.

They must adjust psychologically to the new changes, develop their cognition and harmony of an inner and outer-self, maintain a healthy person mentally and physically so as to keep up with the social development and requirement of the new era. It is a part of a systematic complex with great influence and practical significance. They must adapt themselves in three aspects; the role of a military person, special way of living as a group and military operations.

\section{The role of a service man or woman}

The military service is a special profession. The role of a military person is decided by the duty and obligation to society. They are supposed to meet the expectations of the people and their duty is the base of the military organization as a group. From the day they join the Army, their values, psycho-composition and behaviors are restricted by the career characteristics and by the society. Therefore, the basic guarantee of a successful service life is that of abiding by and giving a full play to this role. There are 3 criteria in judging whether the behaviors of a service man or women suit their positions and environment.

\subsection{Prolonged time of the role}

The longer a serviceman/woman keeps his/her role or stays in the Army and gets involved in military operations, the stronger his/her ability to adapt to military environment is. 


\subsection{Depth into the role}

They should keep the role within an appropriate range, recognized by the public standards and professional norms.

\subsection{Number of roles}

The more roles he/she plays in the Army, the more adaptable he/she is to the role and stronger and longer the time of the role is.

The characteristics of the role as serviceman/woman are: team spirit, goodconducts, full self-confidence, strong willpower, extraordinary endurance, tough physique, honesty, a strong sense of duty and obligation and self-pride, all of which help to make a true soldier or officer, who is respected by the general public of a society. A qualified professional serviceman/woman must meet the following requirements; full understanding of self-image and clear goals of self-development and military career.

\section{Special life style as a team}

The life style is in a form of being a team in which Interpersonal relationship is established with clear goals in career and characterized by comprehensive abilities to adapt to a new way of life style and new interpersonal relationship.

\subsection{Life style}

The life style of the Army is characterized by its duty, missions and specialty of its task, which all the other aspects must be geared to; food, accommodation, recreational and cultural activities, values, morals and aesthetic conceptions.

During certain period of time in history and under certain circumstances, the life style of the Army is an important part of military socialization and guides the direction, essence and level of the process of individual socialization.

The Army life style changes with the social development. Life styles of different historical periods and social systems have had their impacts directly or indirectly on the cognition, emotions, willpower, behaviors, human values and attitudes toward society.

The management of life in the Army is that of being closed or semi-closed, characterized by group living, central supply and high coordination, order, strict military discipline and regulations. Some personal habits and needs must submit to the interests and the image of the Army as a whole.

We must understand that most of the service men and women going through this "melting pot" have changed greatly and become a new type of "human beings", melting a self-being into a bigger "self-being", and developing into maturity. To become a serviceman/woman gives one an opportunity to remold oneself and excel oneself to have better survival abilities.

Everybody in society must face the reality, seize any opportunities, and acquire different abilities in adapting to the new environment and survive. The Army provides for every young man and woman such an opportunity.

\subsection{Interpersonal relationship}

Group living or collective life style is one of the life styles people choose to live and also the basic motivation of an individual to face society. If a person is rejected by or stays away from the group, he or she will feel lonely, restless and painful. The collective form of life style in the Army can satisfy people's needs to communicate with and learn from each other, cultivate team spirit, and build up emotional links and basis of interpersonal relationships.

The life in the Army can make people's behavior and reaction be accepted by the group and society. The way of reaction to outside information is the key to establish and maintain interpersonal relationship. There are three promoting and three behavioral factors influencing interpersonal relationship. The former refer to the factors in which an individual can explore and understand oneself to achieve satisfaction in interpersonal relationship. The three factors are: sympathy -the ability to look at the world from others' point of view and to appreciate others' experiences and feelings; mutual understanding -- the ability to understand one's own feelings of experiences and others' as well; reality -- the ability to respect and accept reality.

The behavioral factors guide individuals to behave according to one's own wills at a higher level of manners. They include: honesty -- the ability to interact with others in an honest and positive way; respect -- the ability to care about and trust others with passion; service -- the ability to share other's feelings and experiences and to serve them.

The basic core of team spirit is the common goal and values among fellow comrades and the significance of team spirit is that everyone in the team is aware of the importance to share and enjoy himself in the team and obtain a sense of achievement, progress and pride, which can hardly be achieved by oneself alone. A person has to put his destiny in the hands of others on many occasions during his life time. Good cooperation, mutual trust and help, mutual support, and interdependence in interpersonal relationships are the true meanings of healthy relationship, which can promote things to develop in a peaceful and successful way. 


\section{Military operations}

Military profession is one of the hardest and most noble careers that require great dedication and self-sacrifice. The adaptability to military operations reflects a person's comprehensive abilities in his or her personal traits, intelligence, physique, skills and values.

A military officer must have high moral standards and versatile abilities in organizing and dealing with different local cultures and the people. Military leadership requires high adaptability, creativity and strong ability to lead in difficult and uncertain situations.

A person can benefit from a successful military career for life. The experience in the service enables a person to face life in a calm way, to face fate in a natural way, and to face the world with a heart of mercy. In fact, there are four aspects in the military operations involving adaptability to environment.

\subsection{Strong physique}

A strong physique is a guarantee in military operations, which requires special physical health of the military personnel. The cruel and unusual military operations or war situations need extraordinary physical and psychological fitness that are almost beyond human limits and tolerance.

In order to meet the requirements in military operations, the Army has established a series of training plans and procedures, including military sport competition programs, physical training programs and skill training programs to train the soldiers and officers to become a tough fighting force physically and psychologically, so that they can accomplish military operations under hard and arduous circumstances beyond normal biological limits and under heavy "loads".

\subsection{Staunch willpower}

Young soldiers and officers must be trained to become strongly-willed and firmly confident in themselves in order to accomplish those dangerous, arduous, complicated and unexpected military operations, which come as a stern challenge to test their self-control, self-consciousness and psychological tolerance.

According to different kinds of pressure sources and psychological pressure dimensions faced by the men and women in military operations, the Army has constituted a series of strategies and tactics and different training programs in which the Army can put the troops in real-world situations and let them experience hardships, pains and shocks during military operations, rarely encountered in other careers or occupations.

The highly-developed self-consciousness and initiatives cultivated in the Army enable them to overcome difficulties on their own, without depending on outside help or supervision. The highly-developed cognitive abilities enable them to make a clear distinction between right and wrong, make right decisions and then execute them. The highly-developed judging abilities enable them to control and manipulate their behaviors in order to achieve the planned goals in a spirit of "Never give up, never lose heart. Go, go, go to win".

\subsection{Good coordination}

Team coordination is very important in the Army. One of the features of military organizations is that of strong cohesion, which is the core of a team and its members are united closely around it and are proud of it. The members stick strictly to the values and norms commonly agreed up by the team and the team's functions is given a full swing to achieve tactical advantages in future operations.

The members of a team must be highly coordinated, skilled and have a variety of knowledge. They must also be "psychologically-coordinated" in order to deal with different kinds of dangerous and unexpected situations and be highly alert and well-prepared for the future. Team coordination is of great significance in the development and the future of a serviceman and woman.

\subsection{Lofty moral characters}

In the light of social psychology, characters are cultivated in the process of individual socialization under the influence of personal and social interactions and under certain cultural circumstances. A military person's characters are featured by the military career and have a direct influence on the fighting capacities and successful completion of the missions.

The quality of moral characters of officers is the key of the whole team performance. The sense of pride and faith is the key of the common value system of the Army. The characters of the servicemen are typical, special, identical, adjustable, and influenced by the environment of military operations.

The creative characters of contemporary servicemen and women are the core of healthy human characters, factors of outstanding character advantages of excellent soldiers and officers and realization of the pursuit of human progress and human life.

Experiences of failures and successes and values of healthy human characters are of great significance to give impetus 
to social progress, to advance personal characters and all-around development of the military personnel and to win the victory of our great cause.

\section{References}

Cronin. (2006). Introduction to Military Psychology. (2nd Edition) Translated by Wang Jing-sheng, et al. Beijing: China Light Industry Publishing House.8.50-51.

Liu, Ning and Xie, Jinning. (2007). Assessment of Career Success from Dual Aspects of Career. Economic and Management Research, 04, 84.

Wang, Jingsheng. (2005). The Making of a Brave Soldier. Psychology \&Health, 8,13-15. 